\title{
Hungarian place names from a Moroccan perspective
}

\author{
Alasli Malak ${ }^{\mathrm{a}, *}$ \\ ${ }^{a}$ Institute of Cartography and Geoinformatics, ELTE Eötvös Loránd University, Budapest, alaslima@map.elte.hu \\ * Corresponding author
}

\begin{abstract}
:
Hungarian, or "Magyar," is a Finno-Ugric language that is different from the other European languages. Despite existing within an Indo-European environment and experiencing some Latinization (Indo-Europeanization), it has retained its distinct characteristics. Nevertheless, it also has some linguistic features, such as a phonetic structure that carries no specific sounds that cannot be easily uttered by a French, Italian, German, or English speaker, rendering it relatively easier for speakers of some Indo-European languages. On the other hand, Morocco has a multilingual environment, with Standard Arabic and Berber (Amazigh) as official languages, along with French and dialectal Arabic. Thus, the coexistence of these languages allowed for a bilingual representation of place names; an Arabic endonym and a French exonym. Both variants hold an official status and are used in maps and road signs. Therefore, the goal of this study is to record Moroccans' pronunciation of Hungarian place names. It is worth investigating whether such Arabic speakers with French knowledge will have difficulty reading the Hungarian toponyms and what is the reasoning behind such difficulty.
\end{abstract}

Keywords: languages, phonetic transcription, toponyms

\section{Introduction}

Space is "a society of place names just as people are landmarks within the group. Places and individuals alike are designated proper names, which can be substituted for each other in many circumstances common to many societies" (Kostanski 2009). Every place has a name, and this name naturally refers to a language. Nearly all names must arise, in the first instance, in the context of one specific language. "As all other names, toponyms belong to languages. Names, in general, are rarely randomly chosen, which is especially true in the case of geographical names" (Tichelaar 2002).

Simply put, toponyms "are, by their very description, names for places" (Kostanski 2004) .Toponyms, or place names, are "linguistic features that refer to a place, be it a city, street, country or other geographical and spatial locations" (Gjesdal 2019). They are "an indispensable component of our communication about geographic features or regions, both natural and man-made." They serve a variety of reasons, including the apparent requirement for unambiguous navigational identification, as well as present territorial claims and the management of a society's past.

Toponyms are usually associated with deeper meanings, "often involving complicated semantics related to language and history, but many toponyms also describe the features they name" (Perdana and Ostermann 2018). Thus, names are "given intentionally, to impart a certain meaning" (Lisa Radding and Western 2010). They are commonly "inscribed on places to which they were first assigned and inherited as such by the people who inhabited the place" (Laaboudi and Marouane 2018). They are frequently "the outcome of a creative process, a subjective interpretation by the local inhabitants at the time of naming." They recurrently endure changes in the local area, "generating historical records of landscape dynamics or land-use changes" (Conedera et al. 2007).

Moreover, A toponym is an abstract form that shows a multifaceted face. It is born in response to a set of events, of which it becomes the support. As a result, every toponym is a monument. Aside from its communicative function, the toponym also carries additional values that allow us to understand the psychology of those who developed it. The toponym is "not only a linguistic string of letters or signs, and its variants, integrated into the structure of a given language (endonyms), but it is also present under numerous forms (exonyms) in other languages" (Löfström and Pansini 2005).

Hence, toponymy is "a science that studies place names both by considering the relationship they maintain with the geographic objects they individualize by naming, and by researching their significance, etymology and changes ... that occurred along their history within the process of denomination" (Poenaru 1972). In other words, toponymy refers to the process of identifying a place by its name. It can reveal a place's physical location, history, and culture. In this way, a place's name can be a crucial indicator of its distinct identity. Since the study of place names uses research results from various fields such as linguistics, geography, history, ethnography, sociology, archeology, economics, and so on, toponymy may be considered a border area located at the intersection of several disciplines (Poenaru-Girigan 2013). 
Toponymy is a live image that frequently reflects a people's identity and culture. It is often a reflection of a person's personality and culture. When paired with history, toponymy denotes or specifies ancient peoples' movements, migrations, colonization areas, and territories where a linguistic group has left its mark. It is a "true reflection of the linguistic history of a particular geographical location and, through this linguistic history, it also is an accurate reflection of history in general." (Ballester, Esteban, and Lacasta 2014).

"Every placename has a story behind it - the name was bestowed by someone, at a particular time and for a particular reason, and sometimes the name is changed for various reasons" (Tent 2015). They serve as "symbols of regional culture and thus reflect the history, habitat, and environment of a place (Qian, Kang, and Weng 2016). The use of toponyms can be perceived as a "practice of creating meaningful places," and naming can be deemed a pivotal practice in "the individual, subjective appropriation of space" (Gjesdal 2019). Toponyms are a concrete indication of the presence of communities that see them as a source of identification and togetherness. Toponyms are cultural validation and territorial validity evidence. Toponyms, like people, have a long history. A toponym is a culmination of hundreds, if not thousands, of years of evolution. They are "not simply labels that identify certain points of space but portals of social change, history, and the use and perception of the environment" (Reszegi 2020).

In a nutshell, the toponym frequently employs linguistic components whose sole purpose is to qualify locations. Moreover, because of their linguistic components, place names already have a meaning that encapsulates the entire history of the relationships between the persons who have lived in the designated environment (Cyprienne 1995). Toponyms, "as elements of language, are also the products of the human mind, produced by people living in communities" (Reszegi 2012). It not only accomplishes a geographical denomination but also draws complex semantic paths, contingent and sometimes original, through the cultural, identity, affective, and memorial frameworks of a subject or group. Within an approach to linguistic and discursive facts that articulates discourse and cognition, the toponym can be considered a place of discursive memory and a socio-cognitive organizer allowing speakers to build a collective story.

\subsection{Hungarian language}

Hungarian, or "Magyar," is a language "spoken by millions well beyond the present borders of the country" (Gercsák 2002). It is a Finno-Ugric language distinct from the rest of Europe. Despite living in an Indo-European setting and undergoing some Latinization (IndoEuropeanization), it has preserved its distinguishing features. It does, however, have some linguistic characteristics, such as a phonetic structure that bears no distinct sounds that cannot be easily said by a French, Italian, German, or English speaker, making it easier for speakers of several Indo-European languages. "The Hungarian written language reflects the pronunciation more accurately than the French or English. The accented vowels (a-á, e-é) may seem peculiar, but they are logical and rational. (Balázs 1997)"

Hungarian is an agglutinative language where grammatical components such as affixes and stems can be added to a word to lengthen it and thus change its meaning. Hungarian is a tough language to learn and communicate in it. It also employs some 'throaty' noises, which are not only challenging to imitate but can also be uncomfortable to use at first.

In contrast to the original Roman alphabet, Hungarian is written using the Roman alphabet plus diacritical markings for vowels and character combinations for consonants. Characters with diacritical markings are regarded as variations of the base letter in some other languages, but in Hungarian, they are considered separate letters.

\begin{tabular}{|c|c|c|c|c|c|}
\hline 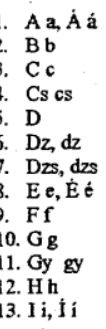 & $\begin{array}{l}{[a, a]} \\
{[b]} \\
{[t s]} \\
[t]] \\
{[d]} \\
{[d z]} \\
{[d z]} \\
{[\varepsilon, \dot{e}]} \\
{[\mathrm{f}]} \\
{[g]} \\
{[\mathrm{F}]} \\
{[\mathrm{h}]} \\
{[\mathrm{i}, \mathrm{i}]}\end{array}$ & 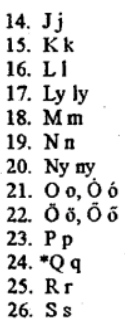 & $\begin{array}{l}{[\mathrm{j}]} \\
{[\mathrm{k}]} \\
{[1]} \\
{[\mathrm{j}]} \\
{[\mathrm{m}]} \\
{[\mathrm{n}]} \\
{[\mathrm{nj}]} \\
{[0,0:]} \\
{[0, \infty:]} \\
{[\mathrm{p}]} \\
{[\mathrm{k}]} \\
{[\mathrm{r}]} \\
{[\mathrm{J}]}\end{array}$ & 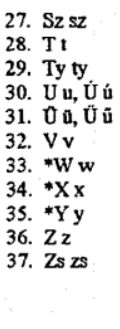 & $\begin{array}{l}{[s]} \\
{[\mathrm{t}]} \\
{[\mathrm{tj}]} \\
{[\mathrm{u}, \mathrm{u}]} \\
{[\mathrm{y}, \mathrm{y}:]} \\
{[\mathrm{v}]} \\
{[\mathrm{v}]} \\
{[\mathrm{ks}]} \\
{[\mathrm{i}]} \\
{[\mathrm{z}]} \\
{[3]}\end{array}$ \\
\hline
\end{tabular}

Figure 1. A list of Hungarian alphabets : source: (UNGEGN 1994)

Other letters that are deemed obsolete can be seen in traditional family names and, in a few cases, geographical names.

$\begin{array}{llllll}c h & [t]] & \text { eö } & {[x]} & \text { th } & {[\text { th }} \\ c z & {[t s]} & \text { ew } & {[x]} & \text { ts } & [t]]\end{array}$

\subsection{Moroccan linguistic situation}

According to (Bennis 2011), Multilingualism characterizes the Moroccan language situation, with each component serving a distinct purpose. Indeed, the cohabitation of native languages, Arabic and Amazigh, with foreign languages, French and Spanish, distinguishes this situation. Each of these languages has a particular place in society and is employed in a limited number of sectors. Arabic, as a standardized variety, is legally the institutional language; non-standardized Arabic ( Moroccan Arabic or Darija) is the vehicle for all Moroccans; Amazigh (Berber) constitutes a vernacular language of natural vitality in rural and urban areas. French is the country's first foreign language and is used as a second language in education and administration. In former Spanish protectorate regions, Spanish is still the first foreign language spoken.

\section{Methodology}

Several themes in toponymic research have arisen due to the merging of elements involved in any toponymic name. On the one hand, a category concerned with studying strictly linguistic phenomena such as morphology, phonetics, syntax, etymology, borrowings, and toponym 
distribution in space. On the other hand, one which prioritizes non-linguistic factors (social, historical, geographic) in the analysis and reveals how toponyms are formed. Toponymic studies tend to be multidisciplinary. The adopted methodology is primarily based on collecting as much recorded data as possible on the pronunciation of Hungarian toponyms by Moroccans. Moreover, the terms place name and toponym are used interchangeably in this paper.

\subsection{Area of study}

Hungary is a landlocked Central European medium-sized country with a surface area of $93,030 \mathrm{~km} 2(35,920 \mathrm{sq} \mathrm{mi})$. It is situated in both the Northern and Eastern hemispheres of the globe and is bordered by 7 Nations: Slovakia in the north; Ukraine in the northeast; Romania in the east; Serbia and Croatia in the south; Slovenia in the southwest and Austria in the west.

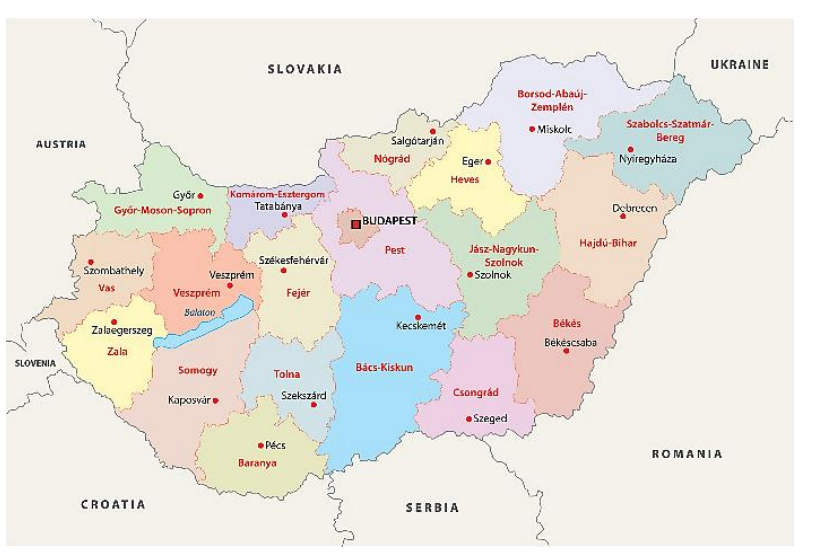

Figure 2. A map of Hungary : source : WorldAtlas

\subsection{Data collection}

Semi-structured interviews, in a form of audio recordings, were the key research method used in this study. In order to avoid any paucity of relevant results, the interviews were administered in Moroccan Arabic, where the participants were able to understand and follow the instructions easily. Thus, 55 participants were given 19 city names, and 15 town names to pronounce.

Considering that a number of the participants may not know Hungary or what language its population uses, the subjects were first presented with a map that shows the country's placement and a short introduction about its linguistic situation.

The toponyms were presented to them both in a list as isolated words and on a map. The participant had the option to choose the most convenient form for them. They were encouraged to read silently before pronouncing the name's pronunciation. Moreover, the toponym's repetition was probed to apprehend some potential intra-speaker variation; they rehearsed individual names until they finally reached their intended pronunciation. Any delays and hesitations in the respondent's responses were recorded; this information was used to estimate the degree of difficulty of some words. "The detection of linguistic regularities that govern foreign place-names' pronunciation by non-native speakers will shed light on its effect on the smooth transmission of information. (Alasli 2021)"

Furthermore, subject instruction is a requisite matter in a non-native speech study; they may feel disquieted about being tested on their foreign language proficiency (in this case, Hungarian). Consequently, the recordings were introduced by a clear explanation of the study's purposes. The participants were urged to use any foreign language knowledge, regardless of potential mistakes. It was reemphasized that the query is not meant as proficiency on the phonetic performance and that correct pronunciation is neither expected nor desired. Although these oral instructions cannot completely compensate for the somewhat contrived experimental situation, they may decrease the subjects' anxiety feelings. The respondents were approached in a more friendly environment to avoid any further pressure that may arise.

Moreover, several participants were interested to know the Hungarian pronunciation of such toponyms. Therefore, a recording from a Hungarian native speaker's pronunciation was obtained beforehand.

\section{Results and discussion}

We recorded the pronunciation of some of the major cities and towns of Hungary. The table below includes the most repeated pronunciations. Individually specific pronunciations were dismissed in order to provide a more coherent data.

\begin{tabular}{|c|c|c|}
\hline Toponym & $\begin{array}{c}\text { Hungarian } \\
\text { pronunciation } \\
\text { (IPA) }\end{array}$ & $\begin{array}{c}\text { Attempted } \\
\text { pronunciations }\end{array}$ \\
\hline Budapest & ['bu:dəpest,_-peft] & $\begin{array}{l}\text { /bu:dapest/ } \\
\text { /bu:dapeft/ } \\
\text { /budapest/ }\end{array}$ \\
\hline Debrecen & ['debretsen] & 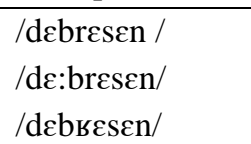 \\
\hline Szeged & ['seged] & 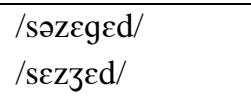 \\
\hline Miskolc & ['mifkolts] & $\begin{array}{l}\text { /miskolz/ } \\
\text { /miskolək/ } \\
\text { /miskolk/ }\end{array}$ \\
\hline Pécs & [pe: $\left.\widehat{t} \int\right]$ & $/ \mathrm{p} \varepsilon \mathrm{ks} /$ \\
\hline Györ & ['zø:r] & $\begin{array}{l}\text { /gjor/ } \\
\text { /зjor/ }\end{array}$ \\
\hline Nyíregyháza & ['ni:rejha:zp] & $\begin{array}{l}\text { /njere-gjahaza/ } \\
1 \\
\text { /njere-zihaza/ }\end{array}$ \\
\hline Kecskemét & ['ketfkeme:t] & /keskemet / \\
\hline
\end{tabular}

${ }^{1}$ The (-) refers to short stop 


\begin{tabular}{|c|c|c|}
\hline Székesfehérvár & ['se:keffehe:rva:r] & $\begin{array}{l}\text { /sczekes- } \\
\text { feheravar/ } \\
\text { /zekes-feher- } \\
\text { var/ }\end{array}$ \\
\hline Szombathely & ['sombbthrj] & $\begin{array}{l}\text { /zombatele:/ } \\
\text { /zombatəle/ } \\
\text { /zombateli/ }\end{array}$ \\
\hline Szolnok & ['solnok] & $\begin{array}{l}\text { /zolnok/ } \\
\text { /səzol-nok/ }\end{array}$ \\
\hline Érd & [e:rd] & $\begin{array}{l}/ \text { /rid/ } \\
/ \varepsilon: \text { rd/ }\end{array}$ \\
\hline Tatabánya & ['totpba:np] & /tatabanja/ \\
\hline Sopron & ['Sopron] & /sopron/ \\
\hline Kaposvár & ['kppofva:r] & $\begin{array}{l}\text { /kapozva:r/ } \\
\text { /kaposva:r/ }\end{array}$ \\
\hline Veszprém & ['vespre:m] & $\begin{array}{l}\text { /ve:zprim/ } \\
\text { /ve:zpxim/ } \\
\text { /vespre:m/ }\end{array}$ \\
\hline Békéscsaba & ['be:ke: $\widehat{\mathrm{t} f \mathrm{pbp}]}$ & $\begin{array}{l}\text { /bcke:s-kaba/ } \\
\text { /bcke:s-ksaba/ } \\
\text { /bcke:s-saba/ }\end{array}$ \\
\hline Zalaegerszeg & ['zDlpegerseg] & $\begin{array}{l}\text { /zale-gerzeg/ } \\
\text { /zale-3erz/ } \\
\text { /zale-3crsəzeg/ }\end{array}$ \\
\hline Eger & [' $\varepsilon \mathrm{g} \varepsilon \mathrm{r}]$ & 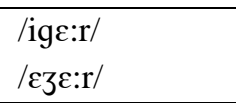 \\
\hline
\end{tabular}

Table 1. Attempted pronunciation of city names

\begin{tabular}{|c|c|c|}
\hline Toponym & $\begin{array}{c}\text { Hungarian } \\
\text { pronunciation } \\
\text { (IPA) }\end{array}$ & $\begin{array}{c}\text { Attempted } \\
\text { pronunciatio } \\
\text { ns }\end{array}$ \\
\hline Nagykanizsa & ['nockpnizp] & $\begin{array}{l}\text { /magikanizəs } \\
\text { a/ } \\
\text { /nazikanizəs } \\
\text { a/ }\end{array}$ \\
\hline Dunakeszi & ['dunvkesi]) & $\begin{array}{l}\text { /dynakezi/ } \\
\text { /dynakesəzi/ }\end{array}$ \\
\hline Dunaújváros & ['dunbu:jva:rof] & $\begin{array}{l}\text { /dynaj- } \\
\text { 3va:ros/ } \\
\text { /dynozvaros/ }\end{array}$ \\
\hline $\begin{array}{l}\text { Hódmezővásárh } \\
\text { ely }\end{array}$ & $\begin{array}{l}\text { ['ho:dmezø:va:Ja:r } \\
\text { hej] }\end{array}$ & $\begin{array}{l}\text { /hodmezo-va- } \\
\text { sarheli/ }\end{array}$ \\
\hline $\begin{array}{l}\text { Szigetszentmikl } \\
\text { ós }\end{array}$ & ['siget.sentmiklo:f] & 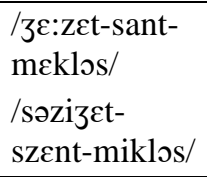 \\
\hline Cegléd & ['tsegle:d] & /scgle:d / \\
\hline $\begin{array}{l}\text { Mosonmagyaró } \\
\text { vár }\end{array}$ & $\begin{array}{l}\text { ['mofonmbjbro:va } \\
\text { :r] }\end{array}$ & $\begin{array}{l}\text { /mosonma- } \\
\text { gja:rova:r/ } \\
\text { /mosnoma- } \\
\text { 3ja:rova:r/ }\end{array}$ \\
\hline
\end{tabular}

\begin{tabular}{|l|l|l|}
\hline Baja & ['bojp] & /baza/ \\
\hline Vác & ['va:ts] & /va:k/ \\
\hline Salgótarján & ['jplgo:tbrja:n] & $\begin{array}{l}\text { /salgo- } \\
\text { tarxan/ } \\
\text { /salgotar- } \\
\text { za:n/ }\end{array}$ \\
\hline Gödöllö & ['gødøllø:] & /godolo/ \\
\hline Ózd & [o:zd] & /szd/ \\
\hline Szekszárd & ['scksa:rd] & $\begin{array}{l}\text { /zegska:rd/ } \\
\text { /szeks-za:rd/ }\end{array}$ \\
\hline Pápa & ['pa:pp] & /pa:pa/ \\
\hline $\begin{array}{l}\text { Hajdúböszörmé } \\
\text { ny }\end{array}$ & ['hojdu:bøsørme:n & $\begin{array}{l}\text { /hazd- } \\
\text { bozormeni/ } \\
\text { /hazdy-bozo- } \\
\text { meni/ } \\
\text { /hazdy- } \\
\text { boszo:-me:ni/ }\end{array}$ \\
\hline & &
\end{tabular}

Table 2. Attempted pronunciation of town names

Certain toponyms, such as Hódmezvásárhely and Szigetszentmiklós, were avoided by many participants. Moreover, some struggled the most in trying to read Hajdúböszörmény, Nagykanizsa, Székesfehérvár, Nyíregyháza, Békéscsaba.

From the recorded pronunciation, we notice the following differences in pronunciations. While $\mathrm{C}$ in Hungarian is a /ts/ sound, Moroccans pronounced it differently. If $\mathrm{C}$ is spelled finally as in "Vác", and "Miskolc", it was pronounced as $/ \mathrm{k} /$, whereas if before an e as in "Debrecen" , and "Cegléd" it was pronounced as an /s/. This is intriguing since it has a resemblance to French orthography. This distinction is also worth noticing because it was made by the participants unconsciously.

CS ( / $\mathrm{t} /$ in Hungarian), SZ (/s/ in hungarian), and ZS (/3/ in Hungarian ) were majorly pronounced as two seperate sounds; namely CS: /k/ + /s/, SZ: /s/ + /z/ , and ZS: /z/ +/s/. Similarly, the consonant blend DZS ( $/ \mathrm{d} z /$ in Hungarian) was pronounced as $/ \mathrm{d} /+/ \mathrm{z} /+/ \mathrm{s} / .82 \%$ agreed that these consonant digraphs were the most confusing elements

$\mathrm{G}$ ( /g/ Hungarian ) was inconsistent where some followed the french spelling rules where they pronounced it as $/ \mathrm{g} /$ unless if it came before e, i, y ( Szigetszentmiklós, Mosonmagyaróvár) and pronounced it as a /3/, while others pronounced it exclusively as a $/ g /$ sound. In addition, Gy , $/ \mathrm{J} /$ in Hungarian ( similar to dy as in tedious) was pronounced either as $/ \mathrm{g} /+/ \mathrm{j} /$ or $/ \mathrm{z} /+/ \mathrm{j} /$.

$\mathrm{J}$ was almost never pronounced as $/ \mathrm{j} /$ but as a $/ 3 /$ sound, and $\mathrm{S}$ was never pronounced as a $/ \mathrm{J} /$ sound but rather as a /s/. $37 \%$ pronounced Budapest as /'bu:dəpeft/ due to their familiarity with such a toponym. Another notable difference in pronunciation is the stress; participants rarely stress the first syllable of a word.

On the other hand, Vowels were tricky mainly due to the existence of diacritical vowels unfamiliar to such a linguistic community. Another major difference is the pronunciation of $\mathrm{A}$, which is mostly pronounced as /a/ by Moroccans, whereas in Hungarian, it is an $/ \mathrm{p} /$ sound 
(similar to O in hot). U /u/, Ú /u:/, ,U /y/, Ü /y:/ were all pronounced as the French $U / y /$ ( as in tu, rue). Moreover, Á/a:/, É /e:/, and Ó /o:/ were pronounced as long vowels. $\mathrm{O}$ and Ö were pronounced as the French $\mathrm{O} / \mathrm{o} /$ by the majority of the participants.

\section{Conclusion}

This study attempted to record Moroccans"' pronunciation of Hungarian place names. The choice of toponyms was based on the major cities and towns of Hungary. The results have shown that the participants have encountered difficulties reading the names. The words intimated some participants where 11 individuals refused to participate in the recording due to the difficulty of such phonetic structure. Reading these Hungarian toponyms was challenging for the majority of the interviewees. The difficulty, they said, stems from the length of the names, the sequence of the vowels, how phonetically inconsistent the words appeared to them, and how unfamiliar the structure of the words is to them. Further research may investigate ways to overcome such problems.

\section{References}

Alasli, Malak. 2021. "Maghrebian Toponym Variants in Hungarian School Atlases." Geodesia Es Kartografia 3(June 2021):29-36. doi: 10.30921/GK.73.2021.3.6.

Balázs, G. (1997). The Story of Hungarian: A Guide to the Language. Corvina Books, Budapest.

Ballester, Emilio Nieto, José A. Rodríguez Esteban, and Pilar Lacasta. 2014. "A Study of the Toponyms of Places and Areas in Relation to the Physical Characteristics of the Terrain of the Province of Cuenca, Spain." Semestrale Di Studi e Ricerche Di Geografia 25(2). doi: 10.13133/1125-5218/24.

Bennis, Saïd. 2011. "La Situation Linguistique Au Maroc : Enjeux et État Des Lieux." Université Mohammed V - Agdal.

Conedera, Marco, Stefano Vassere, Christophe Neff, Manfred Meurer, and Patrik Krebs. 2007. "Using Toponymy to Reconstruct Past Land Use: A Case Study of 'brüsáda' (Burn) in Southern Switzerland." Journal of Historical Geography 33(4):729-48. doi: 10.1016/j.jhg.2006.11.002.

Cyprienne, CHANVOEDOU Yeyinou. 1995. "Etude Des Toponymes Du Gungbe."

Gercsák, Gábor. 2002. "Hungarian Geographical Names in English Language Publications.” Klinghammer, I (Ed.) Cartographic Studies 171-80.

Gjesdal, Ller. 2019. "Travelling Toponymy. The Contribution of Place Names to the Textual Representation of Place and Memory in Abdellah Taïa’s Une Mélancolie Arabe.” 18(1):111-32.

Kostanski, Laura. 2004. "Duel-Names: How Toponyms ( Placenames ) Can Represent Hegemonic Histories and Alternative." 273-93.

Kostanski, Laura. 2009. “'What's in a Name?': Place and Toponymic Attachment, Identity and Dependence:
A Case Study of the Grampians (Gariwerd) National Park Name Restoration Process."

Laaboudi, Mohamed, and Daouia Marouane. 2018. "Interference of Amazigh Naming Patterns in the Arabic Toponymy in Morocco : The Case of Village Names." International Journal of Arabic Linguistics 4(1):163-89.

Lisa Radding, and John Western. 2010. "What's in a Name? Linguistics, Georgraphy, and Toponyms." 100(3):394-412.

Löfström, Jonas, and Valeria Pansini. 2005. "Toponyms and Cartography: Historical Perspective and Linguistic Challenges." Rom J Morphol Embryol 46(2), (Neurofibroma, schwannoma or a hybrid tumor of the peripheral nerve sheath):113-116.

Perdana, Aji Putra, and Frank O. Ostermann. 2018. “A Citizen Science Approach for Collecting Toponyms." ISPRS International Journal of GeoInformation 7(6). doi: 10.3390/ijgi7060222.

Poenaru-Girigan, Oana-Maria. 2013. "The Relationship between Toponymy and Linguistics." Anadiss 8(15):154-66.

Poenaru, Oana-Maria. 1972. "On the Relationship between Toponymy and Linguistics.” 95-102.

Qian, Siwei, Mengjun Kang, and Min Weng. 2016. "Toponym Mapping: A Case for Distribution of Ethnic Groups and Landscape Features in Guangdong, China." Journal of Maps 12:546-50. doi: 10.1080/17445647.2016.1201017.

Reszegi, Katalin. 2012. "Cognitive Approaches to Hungarian Toponymy." Onoma 47(October):36779. doi: 10.2143/ONO.47.0.3085153.

Reszegi, Katalin. 2020. "Toponyms and Spatial Representations." Onomastica LXIV.

Tent, Jan. 2015. "Approaches to Research in Toponymy." Names 63(2):65-74. doi: 10.1179/0027773814Z.000000000103.

Tichelaar, Tjeerd. 2002. "Toponymy and Language.” Pp. $1-17$ in.

UNGEGN. 1994. Toponymic Guidelines for Map and Other Editors. Hungary. 